\title{
Nonparametric design hydrograph in the gauged cross sections of the Vistula and Odra basin
}

\author{
Wiesław Jerzy Gądek, Beata Baziak \\ Cracow University of Technology, Faculty of Environmental Engineering, Institute of Engineering and Water Manage- \\ ment,Warszawska 24,31-155 Kraków, Poland, e-mail: wgadek@iigw.pl, beata.baziak@iigw.pl
}

\author{
Tamara Tokarczyk \\ Institute of Meteorology and Water Management - National Research Institute, Parkowa 30, 51-616 Wroctaw, Poland, \\ e-mail: tamara.tokarczyk@imgw.pl
}

\begin{abstract}
The Archer method for construction of nonparametric hydrographs was regarded as the basic one for constructing design hydrographs in gauged cross sections. The hydrographs designed using this method belong to a group of non-formalized hydrology. Unlike the commonly used formalized methods, where a nonparametric hydrograph is strictly determined and defined, the hydrographs defined in this way are constructed on the assumption, that flow is the main determined parameter. On the other hand, the Archer method assumes that the basic parameter is time, which is determined for assigned standardized flow, called a flow percentile. Hydrographs constructed using this method are the basis for constructing parametric design hydrographs used for engineering computations.

The Archer method is relatively new and should be verified for various regions. Presented manuscript compares the results obtained using this method in the middle Odra and upper Vistula basins with the nonparametric method developed at the Cracow University of Technology, called the Cracow method. The obtained results show, that four highest registered flood waves are sufficient to construct a nonparametric design hydrograph, whereas semi-standardized volumes above descriptors W75 and W50 and the duration time of the descriptors are bigger than the volumes and duration times calculated by means of the Cracow method in the Vistula River basin, and approximate with regard to the values in the Odra River basin.
\end{abstract}

Keywords: the Cracow method, nonparametric hydrograph, the Archer method, flow descriptor, semi-standardized volume

Submitted 15 April 2016, revised 18 October, accepted 19 December 2016

\section{Introduction}

A design flood is usually of parametric type and is constructed on the basis of a nonparametric hydrograph course. By a design hydrograph, the authors understand a flow hydrograph presenting the typical course of a flood wave for a determined cross-section, and which is used for design purposes. Such a flood hydrograph represents a typical basin flood response to heavy rainfall.

Parametric waves are most frequently used for solving problems connected with widely understood flood risk (Vrijling et al. 1998; Apel et al. 2006; Criss, Winston 2008; Hattermann, Kundzewicz 2010; Kriščiukaitienè et al. 2015). Hydrological models are used for their construction (Wałęga 2013; Pietrusiewicz et al. 2014; Wałęga, Grzebinoga 2014). A determined flood wave is the result of an applied model and the assumed distribution of rainfall over time (hyetograph). It is often assumed that the probability of the maximum 24-hour rainfall is the same as the probability of the runoff from a modelled basin. This assumption does not always correspond with real flood development, as has been demonstrated by computational simulations (Gądek, Bodziony 2015). Additional problems involve constructing a hyetograph with an assigned probability of exceedance (Wypych et al. 2014). Rainfall data remains a problem in hydrological modelling, especially in Poland. However, in many countries, for example in the USA, there are recommendations for the design of the shape of hyetographs (Huff 1990; Oliveira, Stolpa 2003). Many researchers seek a solution through the application of integrated hydrological models with distributed parameters, where the limitations connected with basin size are smaller and the models include, in principle, baseflow in the hydrographs (Downer et al. 2000; Ozga-Zielińska et al. 2002). Exponential replacement recessions are also used; these need developing GIS thematic layers for the uniform determination of physical catchment descriptors. Irrespective of the assumed solution, rainfall data remains a problem in hydrological modelling (Jurczyk et al. 2015). As long as this problem remains unresolved, the models must give way to design hydrographs. 
A parametric flood hydrograph is understood as one or two equations describing a nonparametric hydrograph. The methods used for the construction of nonparametric hydrographs comprise methods developed by the Warsaw University of Technology (Gądek 2012), Hydroproject (Gądek, Środula 2014) and the Cracow method (Cracow University of Technology) (Gądek, Tokarczyk 2015), in which hydrographs are constructed using a traditional scheme regarding the flow, and the Archer method using averaging by time (Archer et al. 2000). Parametric hydrographs are constructed using equations developed by: Strupczewski (1964), Baptista and Michel (1990), McEnroe (1992), Ciepielowski (2001) and also parabolic functions (Reed, Marshall 1999) using Gamma distribution, Inverse Gaussian, and Negative Binominal curve (O’Connor et al. 2014), Weibull and Hayashi curve (1986). Another solution is the application of volume formula for basins of less than $400 \mathrm{~km}^{2}$ (Gądek 2014).

This present paper aims to compare hydrographs obtained using the Archer method with hydrographs developed using the Cracow method. In terms of methods of determining hydrograph courses, these methods are totally different. It was assumed that the Cracow method would be modified to make possible the comparison of the values of flow descriptors W75 and W50 and the coefficient of skewness $s$, but also the volume of hydrographs above flow descriptors W75 and W50.

\section{Synthetic description of the Archer nonparametric method}

A nonparametric hydrograph construction method after Archer (Archer et al. 2000) belongs to a group of topics defined as "new hydrology". Figure 1 shows a hydrograph constructed with this method. A nonparametric hydrograph, according to the Archer method, has an indepen-

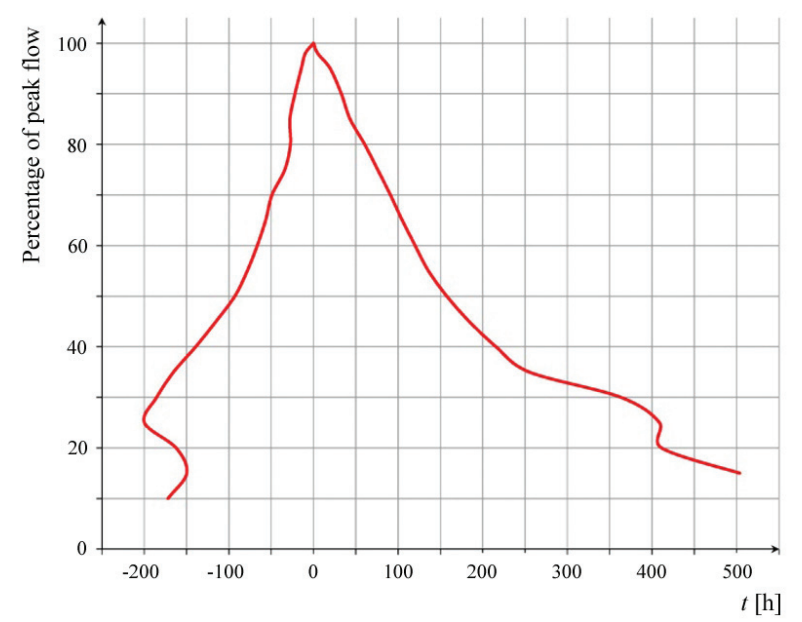

Fig. 1. Nonparametric design hydrograph estimated according to the Archer method dent rising and alling limbs. It is presented in a semi-standard layout, where flow is referred to as a percentile in the range 0 to $100 \%$, while the horizontal axis is the duration time of individual percentile values. In the rising part of the hydrograph, the time assumes negative values and the maximum percentile value of $100 \%$ occurs at the time $t=$ 0 . For the falling part of the hydrograph, the time has positive values and is counted from the maximum percentile value. Individual percentile values are the median values of the flows from the rising limb of the input hydrographs; this is the same for the falling limb. Although the values may be determined using the arithmetic mean, a median is recommended (O'Connor et al. 2014). Input hydrographs should represent the maximum registered floods, not only unimodal, but also multimodal. There is a basic difference in the approach to seeking a hydrograph average reflecting conditions between the Archer method and traditional methods (Gądek, Środula 2014; Gądek, Tokarczyk 2015). No less than 4 hydrographs should be used. However, it should be remembered that this number applies to the hydrographs for which the $75^{\text {th }}$ percentile value may be determined on both limbs. If this condition is not fulfilled, the number should be increased.

The rising limb of a flood hydrograph used to construct a nonparametric design hydrograph should represent nondeclining flows. Individual percentile values result from normalisation through dividing the individual flow ordinates by the maximum value of the hydrograph. The maximum value of such a normalised hydrograph is 1.0 , which corresponds to the $100^{\text {th }}$ percentile value of the peak flow. The percentile values for the falling limb are determined in the same way.

\section{Synthetic description of the Cracow method}

The Cracow method was developed at the Cracow University of Technology in compliance with the principles of formalised hydrology. A normalised unit hydrograph, constructed on the basis of at least 6 or 8 of the highest registered unimodal hydrographs, is used for the construction of a nonparametric hydrograph. The normalised shape of the hydrograph assumes that the flow value changes in the range from 0 to 1 and the hydrograph duration time changes from 0 to 1 for the rising part and from 1 to 2 for the falling part of the hydrograph. The time of the rising limb and falling limb are standardised independently, however, the value of maximum flow is reduced by the flow value $Q_{50 \%}\left(Q_{50 \%}=Q_{\text {med }}-\right.$ median annual flood). Additionally, two linear realationships are determined in this method-describing the relationship between the flood duration time from the rising time, and the reduced volume 

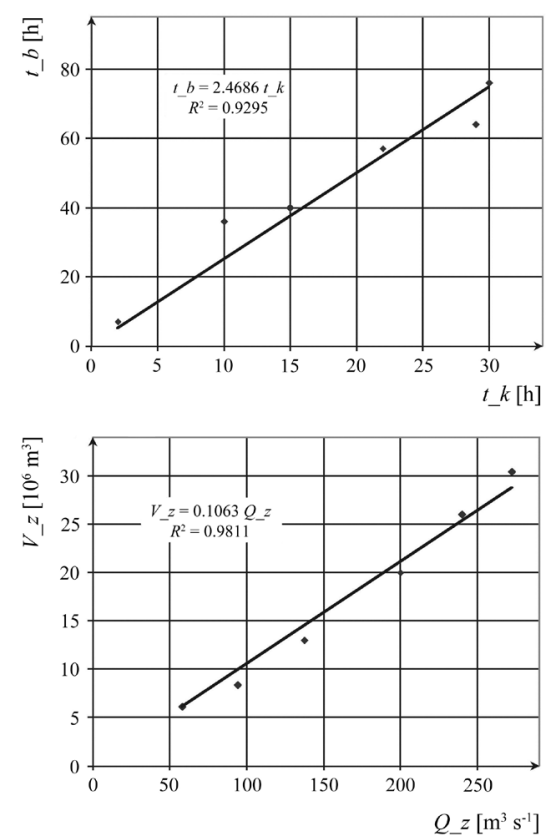

Fig. 2. Dependence of base time $t b b$ on rising time $t k$ and reduced volume $V_{-} z$ (volume above the base flow $Q_{50 \%}$ ) on reduced $Q \_z$; source: own results

(computed for the flows over $Q_{50 \%}$ ) of the maximum reduced flow (flows diminished by $Q_{50 \%}$ ) (Gądek, Tokarczyk 2015). The dependencies are presented in Fig. 2.

In this method, a nonparametric hydrograph is constructed by optimisation, where the rising time is sought for the specified maximum flow. The algorithm involves computing the hydrograph volume from the linear dependence in Fig. 2 and adjusting the rising time so that the computed volume is the most approximate to the specified one established from the dependence $V_{-} z=f\left(Q_{-} z\right)$ (Gądek, Tokarczyk 2015).

\section{Characteristics of the selected basins}

Analysis of the results was conducted on the basis of flow hydrographs observed in 20 gauging cross-sections situated in the area of the upper Vistula and middle Odra river basins. These selected basins represent areas with varied topography. The selection was made so that the basins represented mountainous and submontane, upland and lowland areas. Their characteristics are briefly presented in Table 1, where the gauging stations are ordered according to their belonging to river basins: from 1 to 10 the Vistula River basin and from 11 to 20 the Odra River basin, and regarding their basin areas.

\section{Methods}

In order to conduct comparative analyses it was necessary to modernise a nonparametric hydrograph designed
Table 1. Short characteristics of the basins selected for the comparative calculations; source: own study

\begin{tabular}{|c|l|c|c|}
\hline No. & River - gauging station & $\begin{array}{c}\text { Basin } \\
\text { area } \\
{\left[\mathrm{km}^{2}\right]}\end{array}$ & Basin type \\
\hline \multicolumn{4}{|c|}{ The Vistula River basin } \\
\hline 1 & Grajcarek - Szczawnica & 73,6 & mountain \\
\hline 2 & Uszwica - Borzęcin & 265 & upland \\
\hline 3 & Wisła - Skoczów & 296 & submontane \\
\hline 4 & Raba - Stróża & 644 & submontane \\
\hline 5 & Przemsza - Jelé́ & 2006 & upland \\
\hline 6 & Poprad - Stary Sącz & 2071 & submontane \\
\hline 7 & Nida - Brzegi & 3359 & lowland \\
\hline 8 & San - Przemyśl & 3686 & submontane \\
\hline 9 & Dunajec - Żabno & 6735 & upland \\
\hline 10 & Wisła - Zawichost & 50732 & lowland \\
\hline \multicolumn{4}{|c|}{ The Odra River basin } \\
\hline 11 & Nysa Kłodzka - Międzylesie & 49,7 & mountain \\
\hline 12 & Bystrzyca - Jugowice & 122 & mountain \\
\hline 13 & Czarna Woda - Gniechowice & 251 & submontane \\
\hline 14 & Biała Głuchołaska - Głuchołazy & 283 & submontane \\
\hline 15 & Bóbr - Wojanów & 535 & mountain \\
\hline 16 & Bystrzyca - Jarnołtów & 1721 & upland \\
\hline 17 & Nysa Kłodzka - Bardo & 1744 & submontane \\
\hline 18 & Bóbr - Szprotawa & 2879 & upland \\
\hline 19 & Bóbr - Żagán & 4255 & upland \\
\hline 20 & Odra - Cigacice & 39900 & lowland \\
\hline & & \multicolumn{2}{c|}{} \\
\hline
\end{tabular}

by means of the Cracow method. Therefore, nonparametric hydrographs constructed for the specified value of maximum flow were transformed to the shape corresponding to a design nonparametric hydrograph determined using the Archer method. This standardisation is shown with the following dependence:

$$
q_{i}=\frac{Q_{i}+Q_{50 \%}}{Q_{\max }} 100 \%
$$

where: $q_{i}-$ a percentile of flow at the $i$-th time step [\%], $Q_{i}$ - temporary flow of nonparametric hydrograph at the $i$-th time step in the Cracow method without taking into account the base flow $\left[\mathrm{m}^{3} \mathrm{~s}^{-1}\right], Q_{50 \%}-$ maximum flow with assigned exceedance probability $p=50 \%\left[\mathrm{~m}^{3} \mathrm{~s}^{-1}\right], Q_{\max }-$ maximum flow of nonparametric flood according to the Cracow method $\left[\mathrm{m}^{3} \mathrm{~s}^{-1}\right]$.

The conducted standardisation of the nonparametric flow hydrograph value makes the percentile presentation in the range of 0 to $100 \%$ possible.

For comparison of nonparametric hydrographs constructed using the Archer method and the Cracow method, descriptors W75 and W50 were adopted as reliable indica- 
tors describing the shape of the flood hydrograph. Descriptor W75 is the duration time of the $75^{\text {th }}$ percentile, while descriptor $\mathrm{W} 50$ is the duration time for the $50^{\text {th }}$ percentile. Additionally, the coefficient of skewness $s$ describing the proportion between the rising and falling limb for both descriptors of flow was computed from the following dependence:

$$
s=\frac{W_{W}}{W}
$$

where: $s$ - coefficient of skewness for descriptor W50 or W75 [-], $W_{w}$ - rising time for descriptor W50 or W75 [h], $W$ - duration time of descriptor W50 or W75 [h].

The volumes of nonparametric hydrographs above the assumed flow descriptors W75 and W50 were compared. A relative deviation of the nonparametric hydrograph volume estimated using the Cracow method in relation to the volume of nonparametric hydrograph computed using the Archer method was assumed for the estimation:

$$
E r V=\frac{V_{k}-V_{A}}{V_{A}} 100 \%
$$

where: $E r V$ - relative deviation of the nonparametric hydrograph volume computed using the Archer method for descriptors W75 and W50 [\%], $V_{k}$ - volume of non- parametric hydrograph above descriptor W75 or W50 estimated by the Cracow method $[\mathrm{h}], V_{A}$ - volume of nonparametric hydrograph above descriptor W75 or W50 estimated with the Archer method [h].

The 8 largest flood waves registered for each gauging station were selected for analysis. Three different scenarios were conducted with the Archer method, differentiated by the number of largest flood waves used for computation: 4, 6 and 8 respectively. On the basis of these, 3 nonparametric design hydrographs were constructed. If one or more flood wave had an incomplete rising or falling limb, where they did not reach the $75^{\text {th }}$ percentile, the nonparametric hydrograph using 8 flood waves was not determined. 6 of the greatest unimodal flood waves were used for the Cracow method.

\section{Results}

The results of descriptors W75 and W50 and their corresponding coefficient of skewness $s$ for individual gauging stations are ordered according to the basin area and are shown separately for the Vistula basin in Table 2 and for the Odra basin in Table 3. Sample nonparametric hydrographs, 3 per each basin, are shown in Fig. 3.

Analysing the obtained results, it can be concluded that the Archer method and the Cracow method are similar in the Odra River basin with regard to the flow descriptors
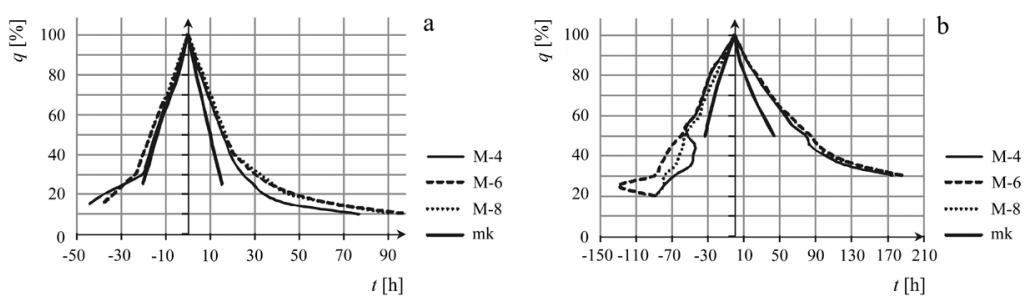

$t[\mathrm{~h}]$
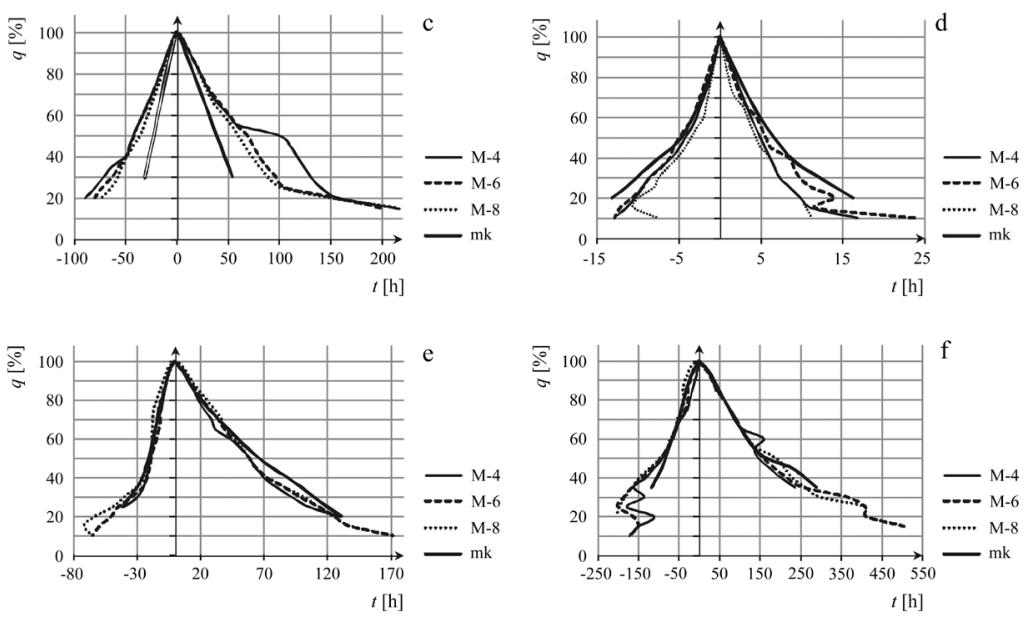

Fig. 3. Nonparametric hydrographs constructed with the Archer method for 4, 6 and 8 flood waves (respectively hydrographs M-4, M-6 and M-8) and by the modified Cracow method (mk hydrograph) for the following gauging stations: a. Grajcarek - Szczawnica, b. Przemsza - Jeleń, c. Wisła - Zawichost, d. Nysa Kłodzka - Międzylesie, e. Bystrzyca - Jarnołtów, f. Odra - Cigacice; source: own results 
Table 2. List of duration times of descriptors W75 and W50 and coefficient of skewness $s$ at the application of the 4 largest flood waves to determine mid-range M-4, taking into consideration 6 flood waves M-6 and 8 flood waves M- 8 in the Archer method and the same descriptors and coefficient of skewness $s$ for nonparametric hydrographs constructed using the modified Cracow method (mk) in the Vistula basin, source: own study

\begin{tabular}{|c|c|c|c|c|c|c|c|c|c|c|}
\hline \multirow{2}{*}{ No } & \multirow{2}{*}{ River-gauging station } & \multirow{2}{*}{ Descriptor } & \multicolumn{6}{|c|}{ The Archer method } & \multicolumn{2}{|c|}{ The Cracow method } \\
\hline & & & M-4 [h] & $\mathrm{S}[-]$ & $\mathrm{M}-6[\mathrm{~h}]$ & $\mathrm{s}[-]$ & $\mathrm{M}-8[\mathrm{~h}]$ & $\mathrm{s}[-]$ & $\mathrm{mk}[\mathrm{h}]$ & $\mathrm{s}[-]$ \\
\hline \multirow{2}{*}{1} & \multirow{2}{*}{ Grajcarek - Szczawnica } & W75 & 13.3 & 0.45 & 14.5 & 0.50 & 16.3 & 0.49 & 10.7 & 0.54 \\
\hline & & W50 & 30.1 & 0.48 & 32.5 & 0.52 & 33.6 & 0.50 & 23.7 & 0.58 \\
\hline \multirow{2}{*}{2} & \multirow{2}{*}{ Uszwica - Borzęcin } & W75 & 17.4 & 0.40 & 15.3 & 0.44 & 14.2 & 0.40 & 18.6 & 0.52 \\
\hline & & W50 & 34.2 & 0.42 & 31.0 & 0.45 & 28.4 & 0.39 & 34.8 & 0.55 \\
\hline \multirow{2}{*}{3} & \multirow{2}{*}{ Wisła-Skoczów } & W75 & 12.8 & 0.37 & 13.0 & 0.34 & 13.4 & 0.35 & 9.1 & 0.34 \\
\hline & & W50 & 24.6 & 0.39 & 26.8 & 0.33 & 27.6 & 0.34 & 18.3 & 0.36 \\
\hline \multirow{2}{*}{4} & \multirow{2}{*}{ Raba - Stróża } & W75 & 11.2 & 0.51 & 12.6 & 0.45 & 12.6 & 0.45 & 6.5 & 0.45 \\
\hline & & W50 & 23.8 & 0.50 & 29.7 & 0.50 & 31.5 & 0.47 & 14.5 & 0.50 \\
\hline \multirow{2}{*}{5} & \multirow{2}{*}{ Przemsza - Jeleń } & W75 & 62.2 & 0.5 & 65.2 & 0.48 & 58.5 & 0.45 & 34.0 & 0.54 \\
\hline & & W50 & 131.7 & 0.4 & 143.9 & 0.41 & 140.3 & 0.4 & 77.3 & 0.43 \\
\hline \multirow{2}{*}{6} & \multirow{2}{*}{ Poprad - Stary Sącz } & W75 & 27.9 & 0.49 & 25.0 & 0.43 & 23.0 & 0.47 & 16.5 & 0.52 \\
\hline & & W50 & 54.8 & 0.51 & 48.3 & 0.45 & 46.8 & 0.45 & 33.8 & 0.54 \\
\hline \multirow{2}{*}{7} & \multirow{2}{*}{ Nida - Brzegi } & W75 & 32.3 & 0.33 & 32.8 & 0.34 & 33.0 & 0.34 & 38.9 & 0.38 \\
\hline & & W50 & 69.2 & 0.30 & 64.4 & 0.33 & 65.1 & 0.33 & 78.3 & 0.38 \\
\hline \multirow{2}{*}{8} & \multirow{2}{*}{ San - Przemyśl } & W75 & 34.2 & 0.64 & 30.0 & 0.66 & 27.1 & 0.70 & 26.8 & 0.68 \\
\hline & & W50 & 58.3 & 0.62 & 66.7 & 0.69 & 55.2 & 0.67 & 53.6 & 0.69 \\
\hline \multirow{2}{*}{9} & \multirow{2}{*}{ Dunajec - Żabno } & W75 & 27.9 & 0.58 & 25.3 & 0.54 & 21.7 & 0.50 & 26.2 & 0.60 \\
\hline & & W50 & 57.2 & 0.58 & 49.9 & 0.51 & 54.1 & 0.47 & 55.1 & 0.57 \\
\hline \multirow{2}{*}{10} & \multirow{2}{*}{ Wisła-Zawichost } & W75 & 48.4 & 0.42 & 48.4 & 0.42 & 44.2 & 0.41 & 32.9 & 0.37 \\
\hline & & W50 & 143.8 & 0.29 & 111.4 & 0.38 & 95.9 & 0.38 & 61.3 & 0.36 \\
\hline
\end{tabular}

Table 3. List of duration times of descriptors W75 and W50 and coefficient of skewness $s$ at the application of the 4 largest flood waves to determine mid-range M-4, taking into consideration 6 flood waves M-6 and 8 flood waves M-8 in the Archer method and the same descriptors and coefficient of skewness $s$ for nonparametric hydrographs constructed using the modified Cracow method (mk) in the Odra basin; source: own study

\begin{tabular}{|c|c|c|c|c|c|c|c|c|c|c|}
\hline \multirow{2}{*}{ No } & \multirow{2}{*}{ River-gauging station } & \multirow{2}{*}{ Descriptor } & \multicolumn{6}{|c|}{ The Archer method } & \multicolumn{2}{|c|}{ The Cracow method } \\
\hline & & & $\mathrm{M}-4[\mathrm{~h}]$ & $\mathrm{s}[-]$ & M-6 [h] & $\mathrm{s}[-]$ & $\mathrm{M}-8[\mathrm{~h}]$ & $\mathrm{s}[-]$ & $\mathrm{mk}[\mathrm{h}]$ & $\mathrm{s}[-]$ \\
\hline \multirow{2}{*}{1} & \multirow{2}{*}{ Nysa Kłodzka - Międzylesie } & W75 & 3.9 & 0.37 & 4.1 & 0.50 & - & - & 4.6 & 0.37 \\
\hline & & W50 & 9.1 & 0.45 & 10.6 & 0.47 & - & - & 11.3 & 0.41 \\
\hline \multirow{2}{*}{2} & \multirow{2}{*}{ Bystrzyca - Jugowice } & W75 & 8.7 & 0.38 & 8.7 & 0.38 & - & - & 12.0 & 0.54 \\
\hline & & W50 & 18.2 & 0.53 & 18.2 & 0.53 & - & - & 28.8 & 0.47 \\
\hline \multirow{2}{*}{3} & \multirow{2}{*}{ Czarna Woda - Gniechowice } & W75 & 39.9 & 0.43 & 38.8 & 0.43 & 38.1 & 0.42 & 39.0 & 0.42 \\
\hline & & W50 & 75.3 & 0.39 & 75.3 & 0.39 & 65.3 & 0.38 & 69.5 & 0.37 \\
\hline \multirow{2}{*}{4} & \multirow{2}{*}{$\begin{array}{l}\text { Biała Głuchołaska - } \\
\text { Głuchołazy }\end{array}$} & W75 & 6.4 & 0.58 & 5.8 & 0.55 & - & - & 11.1 & 0.55 \\
\hline & & W50 & 15.9 & 0.29 & 12.2 & 0.41 & - & - & 30.5 & 0.44 \\
\hline \multirow{2}{*}{5} & \multirow{2}{*}{ Bóbr - Wojanów } & W75 & 15.7 & 0.38 & 20.7 & 0.53 & 20.6 & 0.53 & 28.9 & 0.64 \\
\hline & & W50 & 38.2 & 0.40 & 38.2 & 0.40 & 34.6 & 0.44 & 51.0 & 0.53 \\
\hline \multirow{2}{*}{6} & \multirow{2}{*}{ Bystrzyca - Jarnołtów } & W75 & 36.3 & 0.35 & 40.1 & 0.31 & 47.9 & 0.34 & 38.3 & 0.29 \\
\hline & & W50 & 77.5 & 0.24 & 77.0 & 0.24 & 77.5 & 0.25 & 87.0 & 0.24 \\
\hline \multirow{2}{*}{7} & \multirow{2}{*}{ Nysa Kłodzka - Bardo } & W75 & 10.7 & 0.31 & 11.0 & 0.33 & - & - & 10.7 & 0.45 \\
\hline & & W50 & 26.3 & 0.42 & 28.6 & 0.44 & - & - & 24.8 & 0.43 \\
\hline \multirow{2}{*}{8} & \multirow{2}{*}{ Bóbr - Szprotawa } & W75 & 35.3 & 0.25 & 37.1 & 0.29 & - & - & 43.8 & 0.36 \\
\hline & & W50 & 98.4 & 0.19 & 103.8 & 0.24 & - & - & 127.8 & 0.38 \\
\hline \multirow{2}{*}{9} & \multirow{2}{*}{ Bóbr - Żagań } & W75 & 45.2 & 0.23 & 49.3 & 0.29 & 48.8 & 0.33 & 49.6 & 0.34 \\
\hline & & W50 & 114.8 & 0.25 & 111.6 & 0.26 & 113.2 & 0.27 & 128.7 & 0.24 \\
\hline \multirow{2}{*}{10} & \multirow{2}{*}{ Odra - Cigacice } & W75 & 105 & 0.28 & 109.8 & 0.31 & 117.0 & 0.35 & 119.3 & 0.38 \\
\hline & & W50 & 235.7 & 0.38 & 250.4 & 0.37 & 285.2 & 0.34 & 248.1 & 0.33 \\
\hline
\end{tabular}


Table 4. List of nonparametric hydrograph volumes constructed with the Archer method for 4, 6 and 8 of the largest flood waves and with the Cracow method above flow descriptors W75 and W50; source: own study

\begin{tabular}{|c|c|c|c|c|c|c|c|c|c|}
\hline \multirow{3}{*}{ No } & \multirow{3}{*}{ River-gauging station } & \multicolumn{8}{|c|}{ Nonparametric hydrograph volumes above descriptors [h] } \\
\hline & & \multicolumn{4}{|c|}{ Descriptor W75 } & \multicolumn{4}{|c|}{ Descriptor W50 } \\
\hline & & V_M-4 & V_M-6 & V_M-8 & V_mk & V_M-4 & V_M-6 & V_M-8 & V_mk \\
\hline \multicolumn{10}{|c|}{ The Vistula River basin } \\
\hline 1 & Grajcarek - Szczawnica & 161 & 181 & 204 & 126 & 708 & 773 & 829 & 560 \\
\hline 2 & Uszwica - Borzęcin & 203 & 192 & 179 & 243 & 837 & 771 & 712 & 912 \\
\hline 3 & Wisła - Skoczów & 181 & 170 & 175 & 113 & 637 & 654 & 674 & 454 \\
\hline 4 & Raba - Stróża & 140 & 158 & 154 & 80 & 563 & 667 & 667 & 339 \\
\hline 5 & Przemsza - Jeleń & 791 & 791 & 696 & 413 & 3170 & 3296 & 3079 & 1806 \\
\hline 6 & Poprad - Stary Sącz & 349 & 313 & 288 & 203 & 1382 & 1229 & 1157 & 832 \\
\hline 7 & Nida - Brzegi & 121 & 111 & 112 & 128 & 247 & 232 & 234 & 273 \\
\hline 8 & San - Przemyśl & 468 & 376 & 370 & 349 & 1624 & 1546 & 1347 & 1354 \\
\hline 9 & Dunajec - Żabno & 388 & 322 & 286 & 321 & 1464 & 1260 & 1246 & 1336 \\
\hline 10 & Wisła-Zawichost & 647 & 650 & 615 & 434 & 2680 & 2613 & 2331 & 1611 \\
\hline \multicolumn{10}{|c|}{ The Odra River basin } \\
\hline 11 & Nysa Kłodzka - Międzylesie & 48 & 51 & - & 54 & 206 & 228 & - & 247 \\
\hline 12 & Bystrzyca - Jugowice & 119 & 115 & - & 131 & 447 & 443 & - & 624 \\
\hline 13 & Czarna Woda - Gniechowice & 651 & 565 & 563 & 546 & 2021 & 1908 & 1836 & 1887 \\
\hline 14 & Biała Głuchołaska - Głuchołazy & 105 & 82 & - & 113 & 348 & 290 & - & 460 \\
\hline 15 & Bóbr - Wojanów & 286 & 319 & 323 & 351 & 922 & 1018 & 997 & 1351 \\
\hline 16 & Bystrzyca - Jarnołtów & 491 & 538 & 661 & 504 & 1872 & 1956 & 2213 & 2056 \\
\hline 17 & Nysa Kłodzka - Bardo & 125 & 127 & - & 129 & 588 & 604 & - & 564 \\
\hline 18 & Bóbr - Szprotawa & 441 & 448 & - & 575 & 2210 & 2327 & - & 2639 \\
\hline 19 & Bóbr - Żagań & 580 & 667 & 649 & 628 & 2399 & 2566 & 2611 & 2803 \\
\hline 20 & Odra-Cigacice & 1303 & 1515 & 1762 & 1688 & 5819 & 5925 & 6357 & 6099 \\
\hline
\end{tabular}
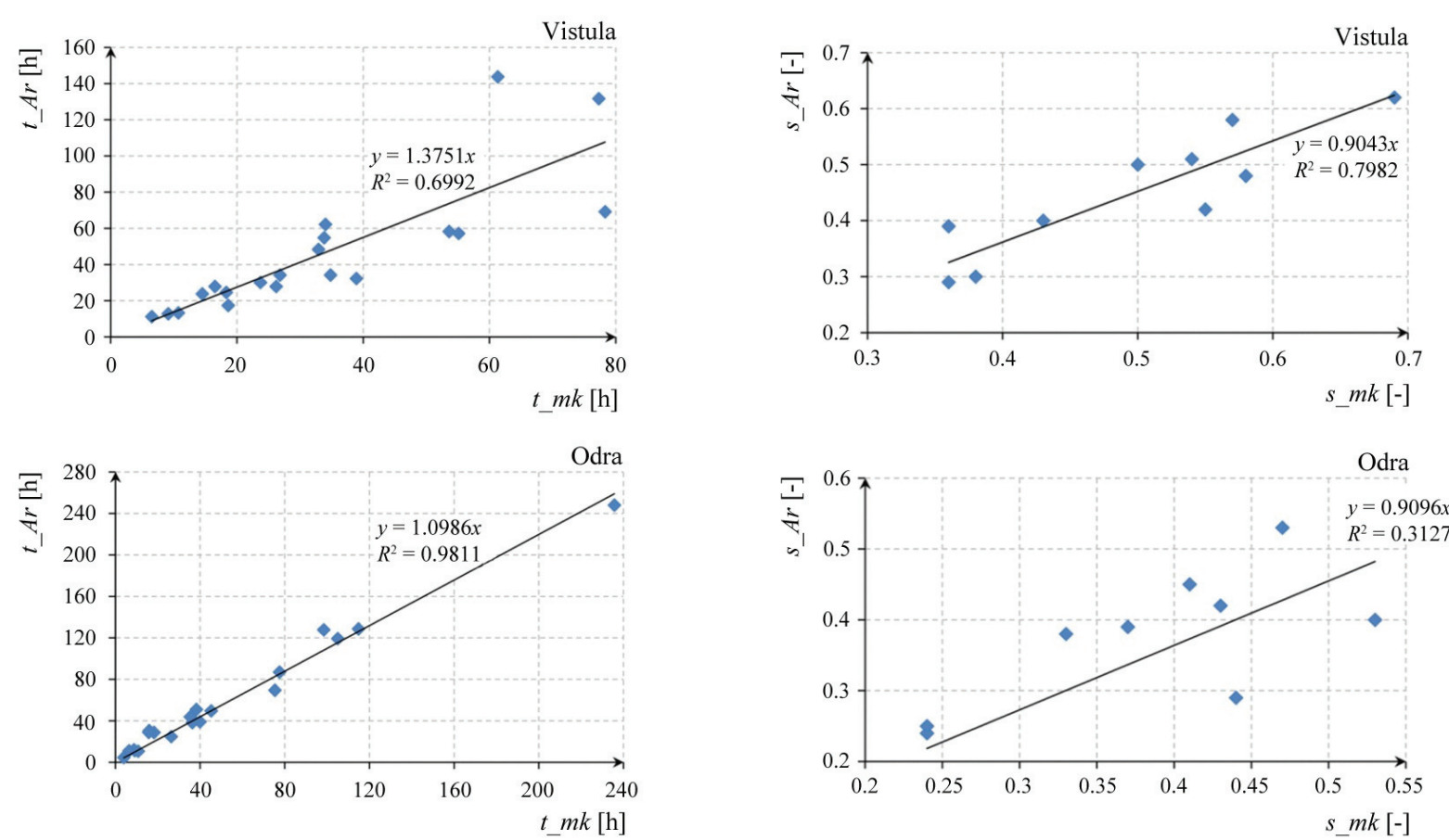

Fig. 4. Dependence of the duration time of flow descriptors W75 and W50 calculated with the Archer method $t \_A r$ for the 4 largest hydrographs on duration time of the descriptors W75 and W50 calculated by the Cracow method $t m k$ for: Vistula River basin and Odra River basin

Fig. 5. Dependence of coefficient of skewness $s$ for the flow descriptor W50 calculated with the Archer method $s_{-} A r$ for the 4 largest hydrographs on coefficient of skewness $s$ for the flow descriptor W50 calculated with the Cracow method $s$ mk for Vistula River basin and Odra River basin 
Table 5. List of relative deviations of nonparametric hydrographs constructed with the Cracow method with reference to nonparametric design hydrographs constructed with the Archer method (formula 3) for the 4, 6 and 8 largest flood waves, for hydrograph volumes above flow descriptors W75 and W50; source: own study

\begin{tabular}{|c|c|c|c|c|c|c|c|}
\hline \multirow{3}{*}{ No. } & \multirow{3}{*}{ River-gauging station } & \multicolumn{6}{|c|}{ Relative volume error acc. to formula $3[\%]$} \\
\hline & & \multicolumn{3}{|c|}{ Descriptor W75 } & \multicolumn{3}{|c|}{ Descriptor W50 } \\
\hline & & M-4 & M-6 & M-8 & M-4 & M-6 & M-8 \\
\hline \multicolumn{8}{|c|}{ Vistula River basin } \\
\hline 1 & Grajcarek - Szczawnica & -21.7 & -30.4 & -38.2 & -20.9 & -27.6 & -32.4 \\
\hline 2 & Uszwica - Borzęcin & 19.7 & 26.6 & 35.8 & 9.0 & 18.3 & 28.1 \\
\hline 3 & Wisła-Skoczów & -37.6 & -33.5 & -35.4 & -28.7 & -30.6 & -32.6 \\
\hline 4 & Raba-Stróża & -42.9 & -49.4 & -48.1 & -39.8 & -49.2 & -49.2 \\
\hline 5 & Przemsza - Jeleń & -47.8 & -47.8 & -40.7 & -43.0 & -45.2 & -41.3 \\
\hline 6 & Poprad - Stary Sącz & -41.8 & -35.1 & -29.5 & -39.8 & -32.3 & -28.1 \\
\hline 7 & Nida-Brzegi & 5.8 & 15.3 & 14.3 & 10.5 & 17.7 & 16.7 \\
\hline 8 & San - Przemyśl & -25.4 & -7.2 & -5.7 & -16.6 & -12.4 & 0.5 \\
\hline 9 & Dunajec - Żabno & -17.3 & -0.3 & 12.2 & -8.7 & 6.0 & 7.2 \\
\hline 10 & Wisła-Zawichost & -32.9 & -33.2 & -29.4 & -39.9 & -38.3 & -30.9 \\
\hline \multicolumn{8}{|c|}{ Odra River basin } \\
\hline 11 & Nysa Kłodzka - Międzylesie & 12.5 & 5.9 & - & 19.9 & 8.3 & - \\
\hline 12 & Bystrzyca - Jugowice & 10.1 & 13.9 & - & 39.6 & 40.9 & - \\
\hline 13 & Czarna Woda-Gniechowice & -16.1 & -3.4 & -3.0 & -6.6 & -1.1 & 2.8 \\
\hline 14 & Biała Głuchołaska - Głuchołazy & 7.6 & 39.5 & - & 32.6 & 58.6 & 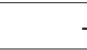 \\
\hline 15 & Bóbr - Wojanów & 22.7 & 10.0 & 8.7 & 46.5 & 32.7 & 35.5 \\
\hline 16 & Bystrzyca - Jarnołtów & 2.6 & -6.3 & -23.8 & 9.8 & 5.1 & -7.1 \\
\hline 17 & Nysa Kłodzka - Bardo & 3.2 & 1.6 & - & -4.1 & -6.6 & - \\
\hline 18 & Bóbr - Szprotawa & 30.4 & 28.3 & - & 19.4 & 13.4 & - \\
\hline 19 & Bóbr-Żagań & 8.3 & -5.8 & -3.2 & 16.8 & 9.2 & 7.4 \\
\hline 20 & Odra-Cigacice & 29.5 & 11.4 & -4.2 & 4.8 & 2.9 & -4.1 \\
\hline
\end{tabular}

W75 and W50. For the Vistula River basin the results are much worse. Figure 4 shows a dependence on the values of descriptors W50 for both methods and in both basins. The opposite relation is found for the coefficient of skewness $s$. A better compliance with both methods was achieved for the Vistula River basin than for the Odra River basin, as shown in Fig. 5. The trend of change was similar for both methods.

The results mainly depend on the data. For the Odra River basin, standard data were available, supplemented with observations of exceptional events; for the Vistula River basin, only daily data with an additional specified term and the maximum flow value were available. However, this does not explain the impact of the number of hydrographs included in the Archer method on the compliance of W50 and W75 in both methods. The greater number of hydrographs included in the Archer method, the greater compliance for both flow descriptors in the methods.

\section{Summary and Conclusions}

In contrast to earlier methods used to determine the nonparametric hydrographs in the Archer method, only the 4 biggest flood hydrographs are required and for their selection there is no restriction on the number of peak flows. The methods used so far in hydrology to determine nonparametric hydrographs could use only unimodal hydrographs, which limited significantly the amount of possible input data, and usually flood hydrographs included in the calculation do not represent the highest recorded flow values.

The conducted analyses revealed that in a majority of cases the nonparametric design hydrographs determined with the Archer method have a larger volume in the Vistula River basin when compared to nonparametric hydrographs determined with the Cracow method. In the Odra River basin these hydrographs reveal much more compliance, not only regarding the volume but also the duration time for descriptors W75 and W50. Contrary to the nonparametric design hydrographs, the coefficient of skewness $s$ for the flow descriptors revealed a greater compliance in the Vistula River basin. Considering the versatility of the Archer method and the simple procedure for the determination of design hydrographs, this method is highly recommended for use in both basins.

The basin area and its location were not observed to fundamentally affected the values of volume and duration 
time of the descriptors in the either of the basins when the Archer method was applied. The Cracow method unfortunately has limitations arising from its complex calculation procedure, which makes it difficult to use.

\section{Bibliography}

Apel H., Thieken A.H., Merz B., Blöschl G., 2006, A probabilistic modelling system for assessing flood risks, Natural Hazards, 38 (1), 295-308, DOI: 10.1007/s11069-005-8603-7

Archer D., Foster M., Faulkner D., Mawdsley H., 2000, The synthesis of design flood hydrographs, [in:] Proceedings of Flooding: risks and reactions, CIWEM/ICE Conference, London, 45-57

Baptista M., Michel C., 1990, Influence des caracteristiques hydrauliques des bies sur la propagation des pointes de crue, La Houille Blanche, 2, 141-148

Ciepielowski A., 2001, Relationships between selected elements of the flood hydrographs in rivers, Journal of Water and Land Development, 5, 89-105

Criss R.E., Winston W.E., 2008, Discharge predictions of a rainfall-driven theoretical hydrograph compared to common models and observed data, Water Resources Research, 44 (10), W10407, DOI: 10.1029/2007WR006415

Downer C.W., Johnson B.E., Ogden F.L., Meselhe E.A., 2000, Advances in physically based hydrologic modeling with CASC2D, Proceedings of Watershed Management and Operations Management, 105, 48 pp.

Gądek W., 2012. Determination of design hydrographs in gauged catchments using the Warsaw University of Technology method and Cracow University of Technology method. Part I. Description of the methods, (in Polish), Czasopismo Techniczne, 2-Ś (23), 94-104

Gądek W., 2014, Theoretical flood waves for non-gauged catchments, (in Polish), [in:]. Hydrologia w inżynierii i gospodarce wodnej, K. Banasik, L. Hajduk, E. Kaznowska (eds.), Monografie KGW-PAN, Warszawa, 139-150

Gądek W., Środula A., 2014, The evaluation of the design flood hydrographs determined with the Hydroproject method in the gauged catchments, Infrastruktura i Ekologia Terenów Wiejskich, 4 (3), 1355-1366

Gądek W., Bodziony M., 2015, The hydrological model and formula for determining the hypothetical flood wave volume in non-gauged basin, Meteorology Hydrology and Water Management, 3 (1), 3-10

Gądek W., Tokarczyk T., 2015, Determining hypothetical floods in the Odra basin by means of the Cracow method and by volume formula, Infrastruktura i Ekologia Terenów Wiejskich, 4 (4), 1507-1519

Hayashi T., Nagamine Y., Nishida A., 1986, A vibration model to describe the lactation curve of a dairy cow, Japanese
Journal of Zootechnical Science, 57 (6), 471-478, DOI: 10.2508/chikusan.57.471

Hattermann F.F., Kundzewicz Z.W. (eds.), 2010, Water Framework Directive: Model supported implementation, A Water Manager's Guide, IWA Publishing, London, 280 pp.

Huff F.A., 1990, Time distributions of heavy rainstorms in Illinois, ISWS/CIR-173/90, Illinois State Water Survey, Champaign, 18 pp., available at: http://www.isws.illinois.edu/ pubdoc/C/ISWSC-173.pdf (data access 29.12.2016)

Jurczyk A., Ośrodka K., Szturc J., Giszterowicz M., Przeniczny P., Tkocz G., 2015, MeteoGIS: GIS-based system for monitoring of severe meteorological phenomena, Meteorology Hydrology and Water Management, 3 (2), 49-61

Kriščiukaitienė I., Baležentis T., Galnaitytė A., Namiotko V., 2015, A methodology for flood risk appraisal in Lithuania, Journal of Water and Land Development, 25 (1), 13-22, DOI: 10.1515/jwld-2015-0008

McEnroe B.M., 1992, Sizing stormwater detention reservoirs to reduce peak flow, [in:] Hydraulic engineering: saving a threatened resource - in search of solutions, Conference Proceedings Paper, Reston, VA, ASCE, 719-724

O’Connor K., Goswami M., Faulkner D., 2014, Flood Studies Update. Technical Research Report. Volume III: Hydrograph Analysis, Derived from Technical Research Reports by NUI Galway and JBA Consulting, 186 pp., available at: http://opw.hydronet.com/default.aspx?page=11 (data access 29.12.2016)

Oliveira F., Stolpa D., 2003, Effect of the storm hyetograph duration and shape on the watershed response, [in:] Proceedings of $82^{\text {nd }}$ Annual Meeting of the Transportation Research Board, Washington, DC, available at: http://www.ltrc.lsu. edu/TRB_82/TRB2003-000341.pdf(data access 29.12.2016)

Ozga-Zielińska M., Gądek W., Książyński K., Nachlik E., Szczepanek R., 2002, Mathematical model of rainfall-runoff transformation - WISTOO, [in:] Mathemalical models of large watershed hydrology, V.P. Singh, D.K. Frevert (eds.), Water Resources Publications, LLC, Littleton, Colorado, $811-860$

Pietrusiewicz I., Cupak A., Wałęga A., Michalec B., 2014, The use of NRCS synthetic unit hydrograph and Wackermann conceptual model in the simulation of a flood wave in an uncontrolled catchment, Journal of Water and Land Development, 23, 53-59, DOI: 10.1515/jwld-2014-0029

Reed D.W., Marshall D.C.W., 1999, Defining a design hydrograph, [in:], Flood Estimation Handbook, vol. 3, CEH, Wallingford, 59-62

Strupczewski W., 1964, Equation of flood crest, (in Polish). Wiadomości Służby Hydrologicznej i Meteorologicznej, 2 (57) $35-58$

Vrijling J.K., van Hengel W., Houben R.J., 1998, Acceptable risk as a basis for design, Reliability Engineering and 
System Safety, 59 (1), 141-150, DOI: 10.1016/S09518320(97)00135-X

Wałęga A., 2013, Application of HEC-HMS programme for the reconstruction of a flood event in an uncontrolled basin, Journal of Water and Land Development, 18, 13-20, DOI: 10.2478/jwld-2013-0002

Wałęga A., Grzebinoga M., 2014, The flood risk assessment in Cracow agglomeration as an element of a flood risk man- agement, (in Polish). Acta Scientiarum Polonarum. Formatio Circumiectus, 13 (4), 259-273

Wypych A., Ustrnul Z., Henek E., 2014, Meteorological hazards - visualization system for national protection against extreme hazards for Poland, Meteorology Hydrology and Water Management, 2 (1), 37-42 